\title{
Structural Characterization of a New Organic Cyclotetraphosphate, $\left[p-\mathrm{ClC}_{6} \mathrm{H}_{4} \mathrm{NH}_{3}\right]_{4} \mathrm{P}_{4} \mathrm{O}_{12}$
}

\author{
Hanène Hemissi, Sonia ABID ${ }^{\dagger}$ and Mohamed Rzaigui
}

Faculté des sciences de Bizerte, Laboratoire de chimie des Matériaux, 7021 Zarzouna Bizerte, Tunisia

\begin{abstract}
Single crystals of a novel cyclotetraphosphate, $\left[p-\mathrm{ClC}_{6} \mathrm{H}_{4} \mathrm{NH}_{3}\right]_{4} \mathrm{P}_{4} \mathrm{O}_{12}$, have been synthesised and characterized by $\mathrm{X}$-ray diffraction. This hybrid compound crystallizes in the monoclinic system, space group $P 2_{1} / a$, with cell dimensions of $a=$ 7.582(1), $b=31.280(9), c=8.052(1) \AA, \beta=117.320(1)^{\circ}$. Its structure is built by $\mathrm{P}_{4} \mathrm{O}_{12}{ }^{4-}$ ring anions and $p$ chloroanilinium cations. The packing of these entities leads to thick layers around the planes $y=0$ and $y=1 / 2$, maintained by electronic interactions and hydrogen bonds.
\end{abstract}

(Received February 28, 2005; Accepted June 20, 2005; Published on web September 9, 2005)

Inorganic organic compounds constitute a vast family of hybrid materials of considerable technological importance. Indeed, due to the nature (molecular, ionic, hydrogen bonding, etc. $)^{1}$ of

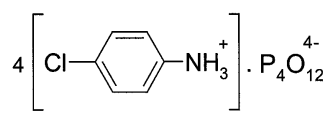

Fig. 1 Chemical diagram of the title compound.

Table 1 Crystal and experimental data

\begin{tabular}{ll}
\hline Chemical formula & $\mathrm{C}_{24} \mathrm{H}_{28} \mathrm{~N}_{4} \mathrm{O}_{12} \mathrm{P}_{4} \mathrm{Cl}_{4}$ \\
CCDC deposit no. & $\mathrm{CCDC}-264420$ \\
Formula weight & 830.21 \\
Crystal system & monoclinic \\
Space group: $P 2_{1} / a$ & $Z=2$ \\
$a=7.582(1) \AA$ & \\
$b=31.280(9) \AA$ & $\beta=117.320(1)^{\circ}$ \\
$c=8.052(1) \AA$ & \\
$V=1696.8(5) \AA^{3}$ & $D_{\mathrm{x}}=1.625 \mathrm{~g} \mathrm{~cm}^{-3}$ \\
Linear absorption factor: & $3.123 \mathrm{~cm}^{-1}$ \\
$F(000)=848$ & \\
Crystal dimensions [mm]: & $0.6 \times 0.4 \times 0.25$ \\
$\theta$ range for data collection: & 2 to $25^{\circ}$ \\
No. of reflections measured: & $6541\left(R_{\text {int }}=0.01\right)$ \\
No. of reflections used: & 3426 with $I>4 \sigma(I)$ \\
No. of parameters: & 217 \\
$R=0.042$ & $R_{\mathrm{w}}=0.044$ \\
Goodness-of-fit $=1.800$ & \\
$(\Delta / \sigma)_{\text {max }}=0.01$ & \\
$(\Delta \rho)_{\max }=0.42$ e $\AA^{-3}$ & \\
$(\Delta \rho)_{\text {min }}=-0.35$ e $\AA^{-3}$ & \\
Measurement & \\
Ag $K_{\alpha}(\lambda=0.5608 \AA)$ & Enraf-Nonius MACH3 \\
Program system & \\
Structure determination & teXsan \\
Refinement & direct method $(\mathrm{SIR} 92)$ \\
\hline & full-matrix on $F$ \\
\hline
\end{tabular}

$\dagger$ To whom correspondence should be addressed.

E-mail: Sonia.abid@fsb.rnu.tn organic and inorganic components, many combinations may be achieved to elaborate suitable materials, such as phosphates, which have been extensively explored in several areas (for example catalysts, sorbents, biotechnological materials)..$^{2-4}$ In this context we report on the synthesis and crystal structure of a new organic cyclotetraphosphate $\left[p-\mathrm{ClC}_{6} \mathrm{H}_{4} \mathrm{NH}_{3}\right]_{4} \mathrm{P}_{4} \mathrm{O}_{12}$ (Fig. 1). This compound was prepared in two steps. In the first one, an aqueous solution of cyclotetraphosphate acid was first prepared by passing a solution of $\mathrm{Na}_{4} \mathrm{P}_{4} \mathrm{O}_{12} \cdot 4 \mathrm{H}_{2} \mathrm{O}$ through an ionexchange resin in its $\mathrm{H}$-state (Amberlite IR 120). The sodium salt was prepared according to a process described by Ondick. ${ }^{5,6}$

Table 2 Final atomic coordinates and $\mathrm{B}_{\text {eq. }}\left(\AA^{2}\right)$ of the non hydrogen atoms of $\left[p-\mathrm{ClC}_{6} \mathrm{H}_{4} \mathrm{NH}_{3}\right]_{4} \mathrm{P}_{4} \mathrm{O}_{12}$

\begin{tabular}{lllll}
\hline Atoms & \multicolumn{1}{c}{$x$} & \multicolumn{1}{c}{$y$} & \multicolumn{1}{c}{$\mathrm{B}_{\mathrm{eq}}$} \\
\hline $\mathrm{Cl}(1)$ & $0.51387(13)$ & $0.23691(2)$ & $0.77829(11)$ & $5.61(2)$ \\
$\mathrm{Cl}(2)$ & $1.0999(2)$ & $0.25411(2)$ & $0.25174(11)$ & $6.07(2)$ \\
$\mathrm{P}(1)$ & $0.23774(6)$ & $0.02182(1)$ & $0.85876(6)$ & $1.576(8)$ \\
$\mathrm{P}(2)$ & $0.53821(6)$ & $0.04025(2)$ & $1.24063(6)$ & $1.648(8)$ \\
$\mathrm{O}(\mathrm{E} 11)$ & $0.0903(2)$ & $0.05017(4)$ & $0.7152(2)$ & $2.39(3)$ \\
$\mathrm{O}(\mathrm{E} 12)$ & $0.1677(2)$ & $-0.01526(4)$ & $0.9258(2)$ & $2.10(3)$ \\
$\mathrm{O}(\mathrm{L} 12)$ & $0.3887(2)$ & $0.00700(4)$ & $0.7808(2)$ & $1.82(2)$ \\
$\mathrm{O}(\mathrm{L} 21)$ & $0.3783(2)$ & $0.05130(4)$ & $1.0294(2)$ & $1.95(2)$ \\
$\mathrm{O}(\mathrm{E} 21)$ & $0.7000(2)$ & $0.07126(4)$ & $1.2996(2)$ & $2.43(3)$ \\
$\mathrm{O}(\mathrm{E} 22)$ & $0.4313(2)$ & $0.03417(4)$ & $1.3537(2)$ & $2.21(3)$ \\
$\mathrm{N}(1)$ & $0.7308(2)$ & $0.05694(5)$ & $0.7307(2)$ & $2.15(3)$ \\
$\mathrm{N}(2)$ & $1.1079(2)$ & $0.06751(5)$ & $0.3738(2)$ & $2.18(3)$ \\
$\mathrm{C}(1)$ & $0.6805(3)$ & $0.10139(6)$ & $0.7455(3)$ & $2.11(4)$ \\
$\mathrm{C}(2)$ & $0.6448(3)$ & $0.11364(7)$ & $0.8913(3)$ & $2.84(4)$ \\
$\mathrm{C}(3)$ & $0.5942(4)$ & $0.15559(7)$ & $0.9023(3)$ & $3.48(5)$ \\
$\mathrm{C}(4)$ & $0.5830(3)$ & $0.18438(7)$ & $0.7691(3)$ & $3.25(5)$ \\
$\mathrm{C}(5)$ & $0.6206(4)$ & $0.17238(7)$ & $0.6251(3)$ & $3.65(5)$ \\
$\mathrm{C}(6)$ & $0.6688(4)$ & $0.13045(7)$ & $0.6117(3)$ & $3.03(5)$ \\
$\mathrm{C}(7)$ & $1.1082(3)$ & $0.11358(6)$ & $0.3452(3)$ & $2.31(4)$ \\
$\mathrm{C}(8)$ & $1.0752(3)$ & $0.14083(7)$ & $0.4602(3)$ & $3.21(5)$ \\
$\mathrm{C}(9)$ & $1.0714(4)$ & $0.18393(7)$ & $0.4308(3)$ & $4.00(6)$ \\
$\mathrm{C}(10)$ & $1.1023(4)$ & $0.19943(7)$ & $0.2869(3)$ & $3.63(5)$ \\
$\mathrm{C}(11)$ & $1.1388(4)$ & $0.17204(7)$ & $0.1713(3)$ & $3.52(5)$ \\
$\mathrm{C}(12)$ & $1.1410(3)$ & $0.12843(7)$ & $0.2007(3)$ & $3.03(5)$ \\
\hline
\end{tabular}

Estimated standard deviations are given in parentheses. $B_{\text {eq }}=4 / 3 \sum_{i} \Sigma_{j} \beta_{i j}\left(\boldsymbol{a}_{i} \cdot \boldsymbol{a}_{j}\right)$. 

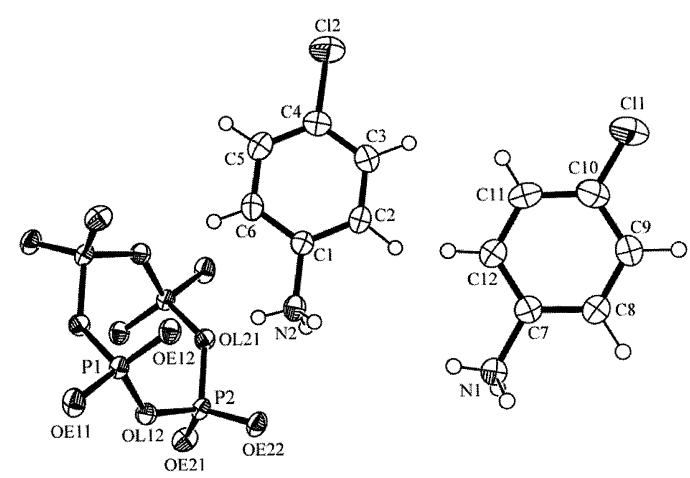

Fig. 2 ORTEP drawing of the cyclic anion $\mathrm{P}_{4} \mathrm{O}_{12}{ }^{4}$ and the two independent $p$-chloroanilinium cations.

Table 3 Hydrogen-bond scheme in $\left[p-\mathrm{ClC}_{6} \mathrm{H}_{4} \mathrm{NH}_{3}\right]_{4} \mathrm{P}_{4} \mathrm{O}_{12}$

\begin{tabular}{ccccc}
\hline D-H $\cdots \mathrm{A}$ & $\mathrm{D}-\mathrm{H}(\AA)$ & $\mathrm{H} \cdots \mathrm{A}(\AA)$ & $\mathrm{D} \cdots \mathrm{A}(\AA)$ & $\mathrm{D}-\mathrm{H} \cdots \mathrm{A}\left({ }^{\circ}\right)$ \\
\hline $\mathrm{N} 1-\mathrm{H} 1 \ldots \mathrm{OE} 11$ & 0.86 & 1.93 & $2.793(3)$ & 176.2 \\
$\mathrm{~N} 1-\mathrm{H} 2 \ldots \mathrm{OE} 22$ & 0.92 & 2.06 & $2.925(3)$ & 155.7 \\
$\mathrm{~N} 1-\mathrm{H} 3 \ldots \mathrm{OE} 12$ & 0.83 & 2.01 & $2.827(3)$ & 167.6 \\
$\mathrm{~N} 2-\mathrm{H} 8 \ldots \mathrm{OE} 22$ & 0.93 & 1.82 & $2.737(3)$ & 167.6 \\
$\mathrm{~N} 2-\mathrm{H} 9 \ldots \mathrm{OE} 12$ & 0.87 & 2.04 & $2.869(3)$ & 157.1 \\
$\mathrm{~N} 2-\mathrm{H} 10 \ldots \mathrm{OE} 11$ & 0.85 & 2.03 & $2.865(3)$ & 171.6
\end{tabular}

In the second step, the obtained acidic solution was rapidly neutralized drop-wise by an ethanolic solution of $p$ chloroaniline. The so-obtained solution was slowly evaporated at room temperature until the formation of colorless crystals with suitable sizes for X-ray analysis. The crystal and experimental data are given in Table 1. All non-hydrogen atoms were refined anisotropically. The hydrogen atom positions were located by difference Fourier syntheses, and were not refined. The final atomic coordinates of the nonhydrogen atoms of $\left[p-\mathrm{ClC}_{6} \mathrm{H}_{4} \mathrm{NH}_{3}\right]_{4} \mathrm{P}_{4} \mathrm{O}_{12}$ and their $B_{\text {eq }}$ are reported in Table 2. An ORTEP drawing of the molecular structure containing one $\mathrm{P}_{4} \mathrm{O}_{12}{ }^{4-}$ ring and the two independent $p$ chloroanilinium groups with the atom labels is shown in Fig. 2.

The crystal structure of $\left[p-\mathrm{ClC}_{6} \mathrm{H}_{4} \mathrm{NH}_{3}\right]_{4} \mathrm{P}_{4} \mathrm{O}_{12}$ can be described as a thick-layered organization built up by $\mathrm{P}_{4} \mathrm{O}_{12}{ }^{4-}$ ring anions and $p$-chloroanilinium cations, and are developed parallel to the $(a, c)$ plane at $y=0$ and $y=1 / 2$. The cohesion of adjacent layers is ensured by weak interactions originating from the organic molecules.

Inside this structure, the $\mathrm{P}_{4} \mathrm{O}_{12}$ ring is located around the inversion centers, $(1 / 2,0,0)$ and $(0,1 / 2,0)$. In this centrosymmetrical entity, the P-P-P angles are 81.45(2) and $98.55(2)^{\circ}$, which reveal a significant distortion of the square formed by the four phosphorus atoms. Nevertheless, this distortion is commonly observed in $\mathrm{P}_{4} \mathrm{O}_{12}$ groups having $C_{\mathrm{i}}$ symmetry. ${ }^{7,8}$ On the other hand, the local arrangement around the $\mathrm{PO}_{4}$ tetrahedron and the $\mathrm{P}-\mathrm{O}-\mathrm{P}$ angles are quite similar to those observed in other condensed phosphoric anions. ${ }^{9}$ In the crystal structure there are two independent $p$-chloroanilinium cations that are associated with phosphoric entities through electrostatic interactions and hydrogen bonds involving hydrogen atoms of $-\mathrm{NH}_{3}$. In all hydrogen bonds, the $p$ chloroaniline nitrogen is a donor atom, whereas the oxygen from the $\mathrm{P}_{4} \mathrm{O}_{12}{ }^{4-}$ ring anions acts as an acceptor atom, with $\mathrm{N} \cdots \mathrm{O}$ separations ranging from 2.737(3) to 2.925(3) $\AA$ (Table 3). The $(\mathrm{N}-\mathrm{C}, \mathrm{C}-\mathrm{C})$ bond lengths and bond angles $(\mathrm{N}-\mathrm{C}-\mathrm{C}, \mathrm{C}-\mathrm{C}-\mathrm{C})$,

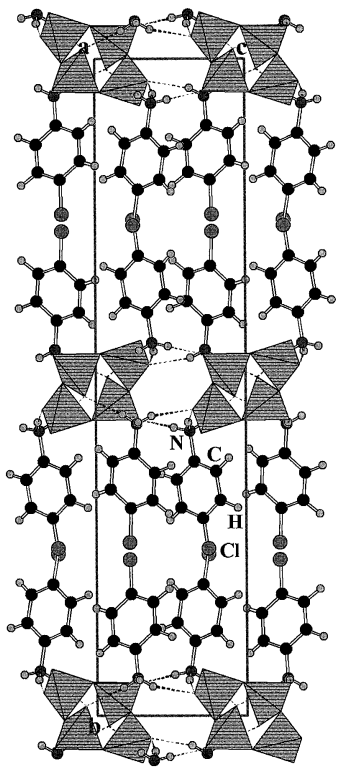

Fig. 3 Atomic arrangement of $\left[p-\mathrm{ClC}_{6} \mathrm{H}_{4} \mathrm{NH}_{3}\right]_{4} \mathrm{P}_{4} \mathrm{O}_{12}$ in projection along the $\mathbf{c}$ direction. The phosphoric anions are given in the terahedra representation. The other atoms are labeled on the figure. The hydrogen bonds are denoted by dotted lines.

ranging from $1.364(4)$ to $1.461(3) \AA$ and from 118.7(2) to $121.6(3)^{\circ}$, respectively, are comparable with those observed in other organic phosphates. ${ }^{10,11}$ The two bond lengths Cl1-C4 (1.736(3) $\AA$ ) and $\mathrm{Cl} 2-\mathrm{C} 10(1.733(3) \AA)$ are within the range of values reported in the literature. ${ }^{12}$ The two $p$-chloroanilinium groups are almost planar with mean deviations of \pm 0.0181 and $\pm 0.0073 \AA$, and are oriented to each other with a dihedral angle of $11.43^{\circ}$. The repartition as well as the orientation of these latter, shown in Fig. 3, are evidently induced by their electronic interactions.

\section{References}

1. F. Neve, A. Crispini, and O. Francescangeli, Inorg. Chem., 2000, 39, 1187.

2. R. C. Finn, J. Zubieta, and R. C. Haushalter, Prog. Inorg. Chem., 2002, 51, 451.

3. B. Koo, W. Ouellette, E. M. Burkholder, V. Golub, C. J. O'Connor, and J. Zubieta, Solid State Sci., 2004, 6, 461.

4. D. Gani and J. Wilkie, Chem. Soc. Rev., 1995, 24, 55.

5. H. M. Ondik, S. Block, and C. H. MacGillavry, Acta Cryst., 1961, 14, 555 .

6. H. M. Ondik, Acta Cryst., 1964, 17, 1139.

7. M. Bdiri and A. Jouini, Acta Cryst., 1990, C46, 1454.

8. H. Hemissi, A. Sonia, and M. Rzaigui, Z. Kristallogr., 2001, 216, 431.

9. A. Durif, "Crystal Chemistry of Condensed Phosphates", 1995, Plenum Press, New York.

10. H. Marouani, M. Rzaigui, and Bagieu-Beucher, Acta Cryst., 2000, C56, 357.

11. J. Fabry, R. Krupkova, and V. Studnicka, Acta Cryst, 2002 , E58, 105.

12. R. Thirumurugan, S. S. Raj, G. Shanmugan, H. K. Fun, V. Raghukumar, and V. T. Ramakrishnan, Acta Cryst., 1999, C55, 1522 . 